\title{
Falling bacterial communities from the atmosphere
}

\author{
Cheolwoon Woo ${ }^{1}$ and Naomichi Yamamoto ${ }^{1,2^{*}}$
}

\begin{abstract}
Background: Bacteria emitted into the atmosphere eventually settle to the pedosphere via sedimentation (dry deposition) or precipitation (wet deposition), constituting a part of the global cycling of substances on Earth, including the water cycle. In this study, we aim to investigate the taxonomic compositions and flux densities of bacterial deposition, for which little is known regarding the relative contributions of each mode of atmospheric deposition, the taxonomic structures and memberships, and the aerodynamic properties in the atmosphere.

Results: Precipitation was found to dominate atmospheric bacterial deposition, contributing to $95 \%$ of the total flux density at our sampling site in Korea, while bacterial communities in precipitation were significantly different from those in sedimentation, in terms of both their structures and memberships. Large aerodynamic diameters of atmospheric bacteria were observed, with an annual mean of $8.84 \mu \mathrm{m}$, which appears to be related to their large sedimentation velocities, with an annual mean of $1.72 \mathrm{~cm} \mathrm{~s}^{-1}$ for all bacterial taxa combined. The observed mean sedimentation velocity for atmospheric bacteria was larger than the previously reported mean sedimentation velocities for fungi and plants.

Conclusions: Large aerodynamic diameters of atmospheric bacteria, which are likely due to the aggregation and/or attachment to other larger particles, are thought to contribute to large sedimentation velocities, high efficiencies as cloud nuclei, and large amounts of precipitation of atmospheric bacteria. Moreover, the different microbiotas between precipitation and sedimentation might indicate specific bacterial involvement and/or selective bacterial growth in clouds. Overall, our findings add novel insight into how bacteria participate in atmospheric processes and material circulations, including hydrological circulation, on Earth.
\end{abstract}

Keywords: Bioprecipitation, Biosedimentation, Bioaerosols, 165 rRNA gene, Aerobiology, Aero-microbiology

\section{Background}

Bacteria are ubiquitous in the lithosphere [1], hydrosphere [2], and atmosphere [3, 4]. Although the number of bacterial species is still not accurately known, a study [5] reported 0.8-1.6 million operational taxonomic units (OTUs) based on sequences of the V4 region of the $16 \mathrm{~S}$ rRNA gene at a $97 \%$ sequence similarity threshold. Bacteria are emitted into the atmosphere with estimated

\footnotetext{
* Correspondence: nyamamoto@snu.ac.kr

'Department of Environmental Health Sciences, Graduate School of Public Health, Seoul National University, Seoul 08826, Republic of Korea

${ }^{2}$ Institute of Health and Environment, Seoul National University, Seoul 08826, Republic of Korea
}

global rates of $0.7-28.1 \mathrm{Tg} \mathrm{y}^{-1}$ [6]. The emitted bacteria play roles in ecological and climate systems, for example, by acting as cloud condensation nuclei and/or iceforming nuclei [6-8]. Moreover, the emitted bacteria eventually settle to the pedosphere by sedimentation (dry deposition) or precipitation (wet deposition), constituting part of the global cycling of substances on Earth, including the water cycle [9].

Bacterial cells are small in size $(0.3-10 \mu \mathrm{m})$ compared to fungal spores $(0.5-30 \mu \mathrm{m})$ and pollen grains $(10$ $100 \mu \mathrm{m})[10,11]$. Small bacterial cells can create small sedimentation velocities, long residence times in the atmosphere, and, therefore, long-range transport, for

(c) The Author(s). 2020 Open Access This article is licensed under a Creative Commons Attribution 4.0 International License, which permits use, sharing, adaptation, distribution and reproduction in any medium or format, as long as you give appropriate credit to the original author(s) and the source, provide a link to the Creative Commons licence, and indicate if changes were made. The images or other third party material in this article are included in the article's Creative Commons licence, unless indicated otherwise in a credit line to the material. If material is not included in the article's Creative Commons licence and your intended use is not permitted by statutory regulation or exceeds the permitted use, you will need to obtain permission directly from the copyright holder. To view a copy of this licence, visit http://creativecommons.org/licenses/by/4.0/ The Creative Commons Public Domain Dedication waiver (http://creativecommons.org/publicdomain/zero/1.0/) applies to the data made available in this article, unless otherwise stated in a credit line to the data. 
example, from Asia to North America [12, 13]. Meanwhile, bacteria can also aggregate and/or attach to other particles to form larger particles [14-16]. Large particles not only generate large sedimentation velocities and flux densities [17-19] but also promote precipitation by serving as giant cloud condensation nuclei, since giant particles $(>2 \mu \mathrm{m})$, and, in particular, ultra-giant particles $(>10 \mu \mathrm{m})$, can effectively collide and scavenge smaller droplets in the air [20, 21]. A recent study [16] reported that precipitation dominated bacterial but not viral deposition, indicating a possibility that larger bacterial particles might selectively serve as giant cloud condensation nuclei.

In addition to particle size, particles' physicochemical properties can also affect nucleation activities. For instance, Pseudomonas syringae is a well-known bacterial species that produces ice nucleation proteins [22-24] and promotes nucleation in the atmosphere. Similarly, several ice-nucleation active bacteria have been reported [25-28] and isolated from clouds [29, 30] and precipitation, including rainfall [9] and snowfall [9, 31, 32]. Thus, bacteria likely play a role and are involved in precipitation, which is generally referred to as "bioprecipitation" $[33,34]$. However, it is still controversial to what extent biological particles, including bacterial particles, contribute to nucleation and are involved in precipitation on a global scale [7, 35-37]. In addition, little is known regarding how precipitation is related to bacterial communities in the atmosphere.

The goal of this study is to investigate the taxonomic compositions and flux densities of bacterial precipitation and sedimentation from the atmosphere. To date, several studies have reported bacterial communities in precipitation [31, 36, 38-41]. However, few studies exist to compare bacterial communities in precipitation to those in sedimentation [39]. The comparison is needed to identify taxa that are uniquely related to precipitation. Moreover, knowledge is scarce regarding taxon-specific bacterial particle sizes [42] that can influence sedimentation velocities and nucleation efficiencies. In our previous fungal study [17], we found that mushroom-forming agaricomycetes were enriched and specifically involved in precipitation. Here, we wished to extend our investigation into bacterial analyses. Specifically, we reanalyze air, sedimentation, and precipitation samples that were previously collected in Seoul in South Korea from May to November 2015 for our fungal [17] and plant [43] analyses. These samples were collected by an automatic dry and wet deposition sampler [44] and a collocated eight-stage Andersen sampler [45]. The samples are reanalyzed here by a bacterialspecific quantitative PCR (qPCR) assay and Illumina MiSeq sequencing, targeting the $\mathrm{V} 3$ and $\mathrm{V} 4$ regions of bacterial 16S rRNA gene.

\section{Results}

\section{Sample statistics}

In total, 30 air samples, collected monthly from May to November 2015, each month with five particle size bins, were sequenced for V3 and V4 regions of the bacterial 16S rRNA gene (Table S1). Air sampling for August failed due to an intense precipitation event. Deposition samples were collected monthly in duplicates from May to November 2015, resulting in a total of 28 libraries consisting of 14 precipitation (wet deposition) and 14 sedimentation (dry deposition) libraries. In total, 1,262, 866 and 1,119,431 high-quality sequence reads were obtained from 30 air sample libraries and 28 deposition libraries, respectively (Table S1). The number of sequence reads ranged from 8425 to 61,239 reads per library. The sequencing depth seems adequate for $\alpha$ diversity analyses, since the rarefaction curves appear to reach to asymptotes, except for two libraries for air samples collected in May (Fig. S1).

\section{Deposition}

Flux densities of atmospheric bacterial depositions were seasonally varied, with peaks observed in May for sedimentation and in July for precipitation (Fig. 1a,b). Similar seasonal trends and strong correlation were observed between the flux densities of bacterial wet deposition and the amounts of precipitation, with their peaks observed in July (Fig. 1b) and with Spearman's $\rho=0.96$ (Fig. S2). The annually averaged flux densities were 1 , 100,000 and 19,400,000 copy number $(\mathrm{CN})$ of $16 \mathrm{~S}$ rRNA gene $\mathrm{cm}^{-2}$ month $^{-1}\left(\mathrm{CN} \mathrm{cm}{ }^{-2}\right.$ month $\left.^{-1}\right)$ for dry and wet deposition, respectively, indicating that 95 and $5 \%$ of bacteria were precipitated and sedimented, respectively, from the atmosphere. However, the month-based contributions of wet deposition seasonally varied from $4.1 \%$ in May to $99.9 \%$ in June (Table S2).

The three most abundant phyla and their mean flux densities were Proteobacteria $\left(952,000 \mathrm{CN} \mathrm{cm}^{-2}\right.$ month $\left.{ }^{-1}\right)$, Actinobacteria $\left(63,000 \mathrm{CN} \mathrm{cm}^{-2}\right.$ month $\left.^{-1}\right)$, and Bacteroidetes $\left(19,000 \mathrm{CN} \mathrm{cm}^{-2}\right.$ month $\left.^{-1}\right)$ for dry deposition (Fig. 1a), and Proteobacteria (17,430,000 CN $\mathrm{cm}^{-2}$ month $\left.^{-1}\right)$, Bacteroidetes $\left(1,460,000 \mathrm{CN} \mathrm{cm}^{-2}\right.$ month $\left.^{-1}\right)$, and Actinobacteria (52,000 CN $\mathrm{cm}^{-2}$ month $^{-1}$ ) for wet deposition (Fig. 1b). At the genus level, bacteria abundant in both dry and wet deposition included Methylobacterium, Sphingomonas, Blastococcus, and Massilia (Fig. 2). The genera specifically enriched in wet deposition included Novosphingobium, Beijerinckia, Phenylobacterium, Ralstonia, Aquabacterium, and Burkholderia (Fig. 2). Pseudomonas was detected at small relative contributions, i.e., 0.065 and $0.003 \%$ of total bacterial sedimentation and precipitation, respectively. 


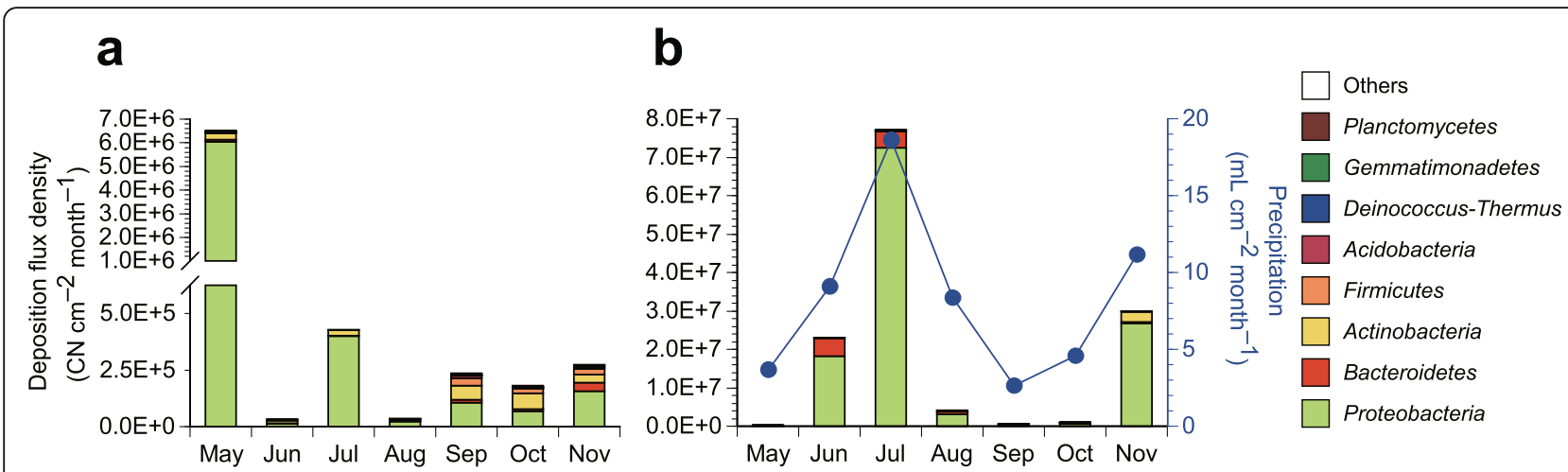

Fig. 1 Bacterial deposition from the atmosphere. a Flux densities of bacterial deposition in the dry form. $\mathbf{b}$ Flux densities of bacterial deposition in the wet form. The precipitation data [17] are shown on the secondary axis

Air

The particle-size-integrated total bacterial concentrations seasonally varied from $5900 \mathrm{CN} \mathrm{m}^{-3}$ to 870,000 $\mathrm{CN} \mathrm{m}{ }^{-3}$ (Fig. 3), with their annual mean concentration of $280,000 \mathrm{CN} \mathrm{m}^{-3}$. The geometric means of the aerodynamic diameters $\left(d_{\mathrm{a}}\right)$ of bacterial particle size distribution range from $5.63 \mu \mathrm{m}$ to $>11.1 \mu \mathrm{m}$ (Fig. 3), with their annual mean of $8.84 \mu \mathrm{m}$, for all bacterial taxa combined. On an annual basis, $25 \%$ of bacteria were of a particle size of $d_{\mathrm{a}}>11 \mu \mathrm{m}$, while the remaining 62 and $13 \%$ of bacteria were in the particle size range of $d_{\mathrm{a}}=3.3-11 \mu \mathrm{m}$ and $d_{\mathrm{a}}=2.1-3.3 \mu \mathrm{m}$, respectively.

The six most abundant phyla and their annual particle-size-integrated concentrations and aerodynamic diameters were Proteobacteria $\left(214,000 \mathrm{CN} \mathrm{m} \mathrm{m}^{-3}\right.$, $9.02 \mu \mathrm{m})$, Actinobacteria $\left(29,000 \mathrm{CN} \mathrm{m}^{-3}, 10.1 \mu \mathrm{m}\right)$, Firmicutes $\left(29,000 \mathrm{CN} \mathrm{m}^{-3}, 7.55 \mu \mathrm{m}\right)$, Bacteroidetes $(3200$ $\left.\mathrm{CN} \mathrm{m} \mathrm{m}^{-3}, 8.85 \mu \mathrm{m}\right)$, Acidobacteria $\left(1100 \mathrm{CN} \mathrm{m}^{-3}\right.$, $8.91 \mu \mathrm{m})$, and Planctomycetes $\left(570 \mathrm{CN} \mathrm{m}^{-3}, 10.4 \mu \mathrm{m}\right)$ (Fig. 3). At the genus level (Fig. 4), the five most abundant bacteria and their annually averaged particle-sizeintegrated concentrations were Methylobacterium (66, $\left.000 \mathrm{CN} \mathrm{m}^{-3}\right)$, Massilia $\left(62,000 \mathrm{CN} \mathrm{m}^{-3}\right)$, Bacillus (9300 $\left.\mathrm{CN} \mathrm{m}{ }^{-3}\right)$, Sphingomonas $\left(6700 \mathrm{CN} \mathrm{m}^{-3}\right)$, and Acinetobacter $\left(4400 \mathrm{CN} \mathrm{m}^{-3}\right)$. The aerodynamic diameters of selected bacterial genera are shown in Table 1 .

\section{Diversity}

Bacterial taxonomic richness was seasonally varied, with primary peaks observed in May for both dry and wet deposition, and secondary peaks in September for dry deposition and in October for wet deposition (Fig. 5a). These tendencies appear to reflect the seasonal tendency in taxonomic richness in the atmosphere, with the primary peak in May and secondary peaks in October (Fig. $5 b)$. However, the future interannual observation is needed to confirm the reproducibility in the observed seasonal tendencies. Bacterial communities were statistically significantly different in terms of dry and wet deposition, both in terms of their memberships $(p<0.0001$; P-test) (Fig. 5c) and structures ( $p<0.0001$; P-test) (Fig. $5 d)$. No significant difference was observed in the bacterial memberships between dry deposition and the air $(p>$ 0.05; P-test) (Fig. 5c).

\section{Sedimentation velocity}

Dry deposition (sedimentation) velocities $\left(V_{\mathrm{d}}\right)$ were calculated according to Eq. (1), which is described in the method section. Briefly, the velocities were calculated by dividing the sedimentation flux densities, measured using the dry deposition sampler by air volumetric concentrations measured using the collocated Andersen sampler. The sedimentation velocity for all bacterial taxa combined was $1.72 \mathrm{~cm} \mathrm{~s}^{-1}$. At the phylum level, the velocities were $2.00 \mathrm{~cm} \mathrm{~s}^{-1}$ for Proteobacteria, $2.64 \mathrm{~cm} \mathrm{~s}^{-1}$ for Bacteroidetes, $0.97 \mathrm{~cm} \mathrm{~s}^{-1}$ for Actinobacteria, 0.26 $\mathrm{cm} \mathrm{s}^{-1}$ for Firmicutes, $1.23 \mathrm{~cm} \mathrm{~s}^{-1}$ for Acidobacteria, and $0.23 \mathrm{~cm} \mathrm{~s}^{-1}$ for Planctomycetes. The sedimentation velocities for the selected genera and their aerodynamic diameters are shown in Fig. 6 and are listed with their microscopy-based sizes in Table 1 . A moderate positive correlation was observed between the sedimentation velocities and aerodynamic diameters for those selected genera (Pearson's $r=0.43$ ) (Fig. 6).

\section{Discussion}

In this study, we measured the flux densities and characterized the taxonomic assemblages of bacteria deposited from the atmosphere in both dry (sedimentation) and wet (precipitation) modes. We also quantified bacterial aerodynamic diameters and sedimentation velocities by the collocation of a volumetric eight-stage Andersen sampler and an automated dry deposition sampler. We found that precipitation contributed to $95 \%$ of 


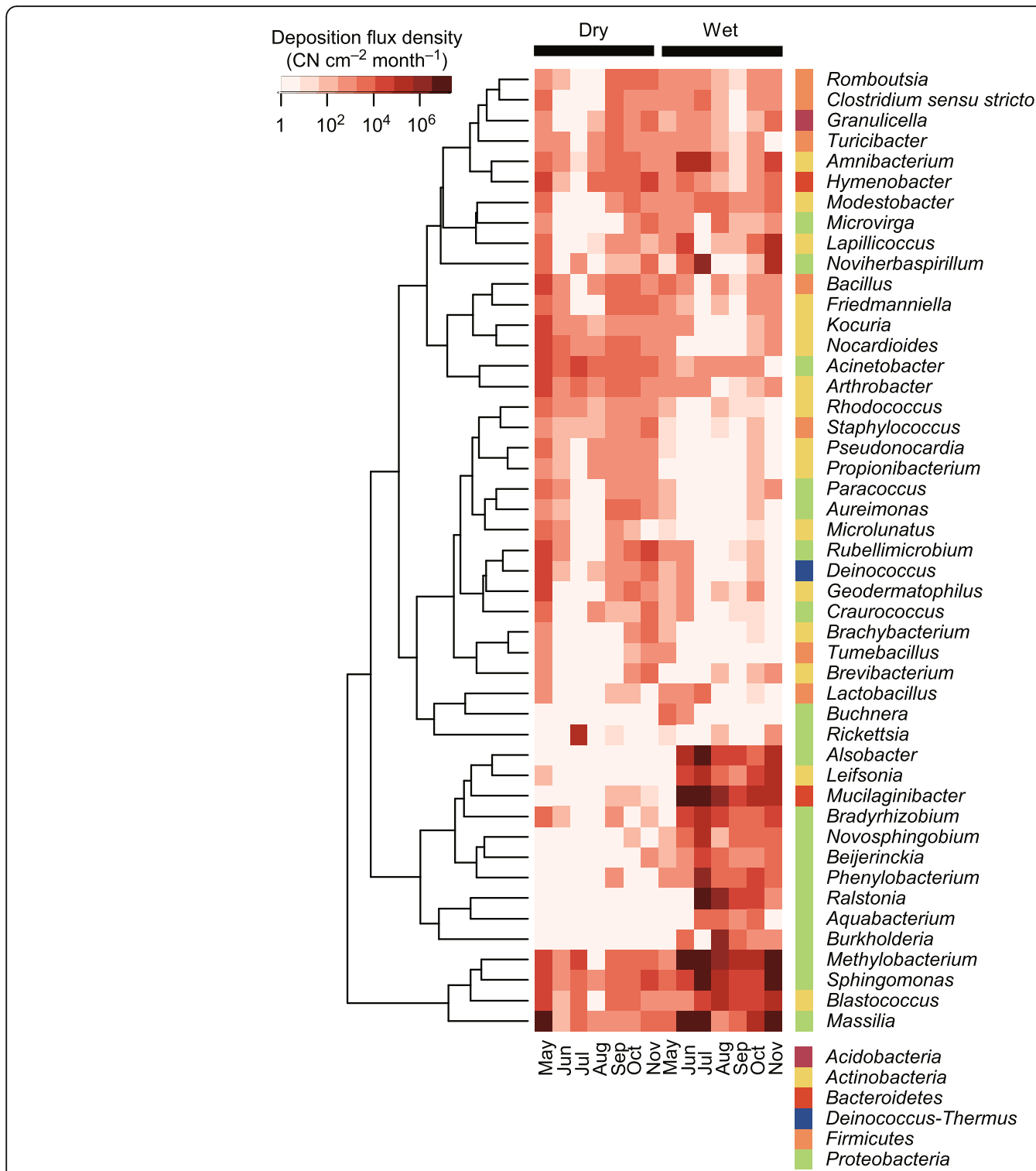

Fig. 2 Flux densities of atmospheric deposition of selected bacterial genera. The 30 most abundant genera in dry and/or wet deposition in terms of the sequence relative abundances are shown. The tree represents the similarities of the log-transformed abundances across genera based on Euclidean distances

atmospheric bacterial deposition (Table 2) and that bacterial assemblages in precipitation were significantly different from those in sedimentation $(p<0.0001$; P-test) (Fig. 5c,d). Moreover, we observed large aerodynamic diameters of atmospheric bacteria (Fig. 3), with an annual mean of $8.84 \mu \mathrm{m}$ (Table 2), which might be related to their large sedimentation velocities (Fig. 6), with an annual mean of $1.72 \mathrm{~cm} \mathrm{~s}^{-1}$ for all bacterial taxa combined (Table 2).

\section{Large aerodynamic diameters of atmospheric bacteria} We found that the mean bacterial aerodynamic diameter $\left(d_{\mathrm{a}}=8.84 \mu \mathrm{m}\right) \quad$ was larger than the previously characterized mean fungal aerodynamic diameter $\left(d_{\mathrm{a}}=\right.$ $5.93 \mu \mathrm{m})$ [17], which is contrary to the reported microscopy-based sizes of $0.3-10 \mu \mathrm{m}$ for bacterial cells and $0.5-30 \mu \mathrm{m}$ for fungal spores $[10,11]$. We also found that the bacterial genus-specific aerodynamic diameters measured in this study were consistently larger than their reported microscopy-based sizes (Table 1), indicating that bacteria aggregate and/or attach to other particles to form larger particles in the atmosphere. Indeed, existing studies [14-16] have reported bacterial aggregation and attachment to other particles.

The large observed aerodynamic diameters of atmospheric bacteria may be partially explained by the 


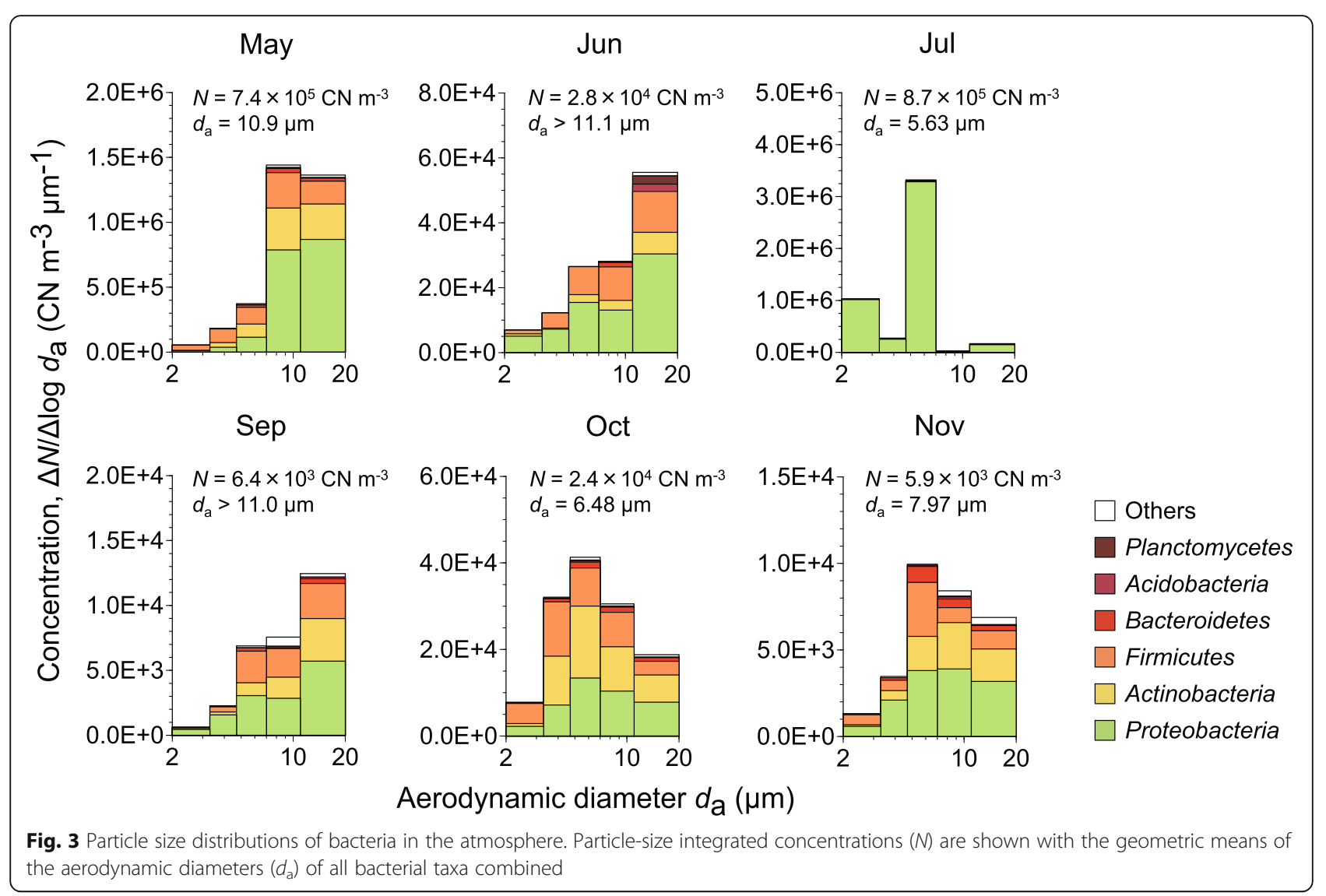

differences in how microbial quantities are characterized by our molecular biology-based approach. Traditionally, a culture-based approach has been used to characterize airborne microbial particle size distributions by enumerating microbial colonies grown on nutrient agar plates loaded in a multi-stage impactor, including the Andersen sampler $[45,67,68]$. For instance, the count median diameters of $2.4-4.8 \mu \mathrm{m}$ and $3.1-4.5 \mu \mathrm{m}$ were reported for airborne culturable bacteria by culture-based studies [69, 70]. However, this approach distorts microbial particle size distributions based on their biomass since it quantitates the number of colonies, each possibly derived from an aggregate of multiple microbial cells. For instance, it quantitates a smaller particle containing a single microbial cell and a larger particle containing multiple cells equivalently to 1 colony forming unit (CFU). This underestimates the microbial biomass in larger particles relative to that in smaller particles, resulting in a measured peak size that is smaller than the actual peak of a given microbial particle size distribution. In this study, we have quantified the number of bacterial $16 \mathrm{~S}$ rRNA gene copies by qPCR, and this approach provides a more proportional measure of bacterial biomass. The proportionality might be possibly distorted by the variability in the number of $16 \mathrm{~S}$ rRNA gene copies per cell [71]. However, there is no evidence that this variability is dependent on bacterial size, so we can reasonably assume that the qPCR-derived bacterial particle size distributions are likely to be proportional to those based on the bacterial biomass.

We observed that a small fraction (13\%) of bacterial $16 \mathrm{~S}$ rRNA gene copies were in a particle size range of $d_{\mathrm{a}}=2.1-3.3 \mu \mathrm{m}$ (Fig. 3). Due to the small bacterial cell size $(0.3-10 \mu \mathrm{m})[10,11]$, it is possible that they exist in smaller particle size fractions, which were not investigated in this study. Indeed, the literature has reported the detection of bacteria from fine particles where $d_{\mathrm{a}}<$ $2.5 \mu \mathrm{m}\left(\mathrm{PM}_{2.5}\right)[72,73]$. Although they constitute relatively minor fractions, these small bacterial particles might contribute to the reported long-range transport (e.g., $[12,13])$ due to long residence times and small sedimentation velocities in the atmosphere. Meanwhile, a larger fraction $(25 \%)$ of bacteria was detected from a particle size fraction of $d_{\mathrm{a}}>11 \mu \mathrm{m}$. Since ultra-giant particles $(>10 \mu \mathrm{m})$ are known to serve as effective giant cloud condensation nuclei [20], these bacterial particles might serve as giant cloud condensation nuclei [21]. Previous studies have reported that ultra-giant particles can 


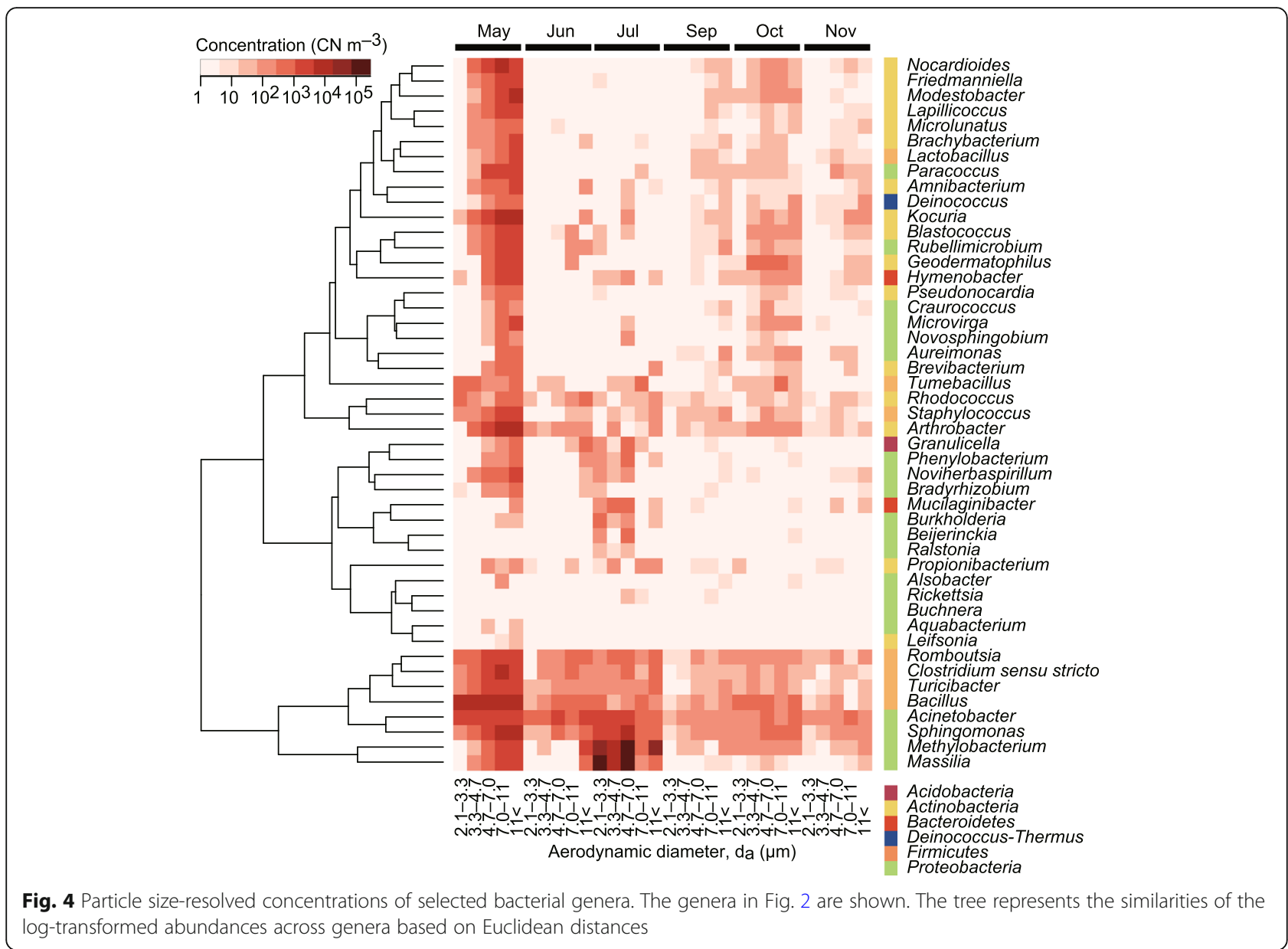

reach cloud base altitudes, e.g., > $1000 \mathrm{~m}[74,75]$, and that bacteria have been detected at cloud base altitudes $(500-2000 \mathrm{~m})$ [76] and even at higher altitudes of the stratosphere $[77,78]$.

We would also like to note large variability in peak aerodynamic diameters of atmospheric bacteria observed each month, ranging from $d_{\mathrm{a}}=5.63 \mu \mathrm{m}$ to $d_{\mathrm{a}}>11.1 \mu \mathrm{m}$ (Fig. 3). We found that the size peaks were inversely associated with the minimum and mean relative humidity observed during each sampling month, with Spearman's $\rho=-0.77$ and -0.60 , respectively, although the results are not statistically significant (Table S3). Particle resuspension (aerosolization) is known to be reduced with increased relative humidity [79]. One possible explanation is that the elevated relative humidity reduced aeolian aerosolization of local bacterial particles, including largesize bacterial particles, while small-size particles remained permitted from non-local distant sources due to their ability of long-range transport. We expect that these particle size-dependent imbalances might be a cause of selective reduction of large-size particles and therefore shifts in the size distributions observed during wet months (e.g., July and November) at our sampling site.

\section{Large sedimentation velocities of atmospheric bacteria}

Large sedimentation velocities were observed for bacteria (Fig. 6 and Table 1), with a mean of $1.72 \mathrm{~cm} \mathrm{~s}^{-1}$, which is greater than that previously reported for the velocities of fungi $\left(0.80 \mathrm{~cm} \mathrm{~s}^{-1}\right)$ [17] and plants $(0.40 \mathrm{~cm}$ $s^{-1}$ ) [43] (Table 2). The large sedimentation velocity was associated with the large aerodynamic diameter of bacteria (Table 2). As discussed above, large bacterial aerodynamic diameters are likely attributed to their aggregation and/or attachment to other particles [1416]. The different mechanisms of atmospheric liberation might explain why bacterial particles were larger than those of fungi and plants that release reproductive particles (e.g., spores and pollen grains) directly from their reproductive organs (e.g., sporangia and stamens) [80]. Due to their direct dispersal from reproductive organs, plant and fungal particles are less likely to be attached to 
Table 1 Atmospheric properties of selected bacterial genera

\begin{tabular}{|c|c|c|c|c|}
\hline Phylum & Genus $^{a}$ & $\begin{array}{l}\text { Sedimentation } \\
\text { velocity, } V_{\mathrm{d}}\left(\mathrm{cm} \mathrm{s}^{-1}\right)^{\mathrm{b}}\end{array}$ & $\begin{array}{l}\text { Aerodynamic } \\
\text { diameter, } d_{\mathrm{a}}(\mu \mathrm{m})^{\mathrm{c}}\end{array}$ & Microscopy-based diameter or width $\times$ length [ref.] \\
\hline \multirow[t]{7}{*}{ Actinobacteria } & Arthrobacter & 0.64 & 8.34 & $0.6-1.0 \mu \mathrm{m}[46]$ \\
\hline & Amnibacterium & 2.5 & 9.99 & $0.15-0.20 \times 0.25-0.30 \mu \mathrm{m}$ for Amnibacterium kyonggiense [47] \\
\hline & Blastococcus & 1.7 & 10.1 & $0.3-1.7 \mu \mathrm{m}[48]$ \\
\hline & Rhodococcus & 1.5 & 8.74 & $\begin{array}{l}0.4-0.6 \times 8-12 \mu \mathrm{m} \text { for filaments and } 0.2-0.5 \times 1.7-3 \mu \mathrm{m} \text { for } \\
\text { cocci or short rods for Rhodococcus jostii [49] }\end{array}$ \\
\hline & Kocuria & 0.42 & 9.31 & $1-1.5 \mu \mathrm{m}$ for Kocuria rosea $[50]$ \\
\hline & Brachybacterium & 0.54 & 10.3 & $0.5-0.75 \times 1.5-2.5 \mu \mathrm{m}$ for Brachybacterium faecium [51] \\
\hline & Propionibacterium & 1.6 & 8.54 & $\begin{array}{l}0.2-1.5 \times 1-5 \mu \mathrm{m} \text { for pleomorphic rods, } 20 \mu \mathrm{m} \text { in length for } \\
\text { filaments, and } 5-20 \mu \mathrm{m} \text { for swollen spherical cells [52] }\end{array}$ \\
\hline Bacteroidetes & Mucilaginibacter & 0.086 & 5.32 & $0.43-0.49 \times 1.4-1.8 \mu \mathrm{m}$ for Mucilaginibacter gynuensis [53] \\
\hline \multirow[t]{5}{*}{ Firmicutes } & Bacillus & 0.18 & 6.75 & $0.4-1.8 \times 0.9-10.0 \mu \mathrm{m}[54]$ \\
\hline & Turicibacter & 0.30 & 8.15 & $0.5-2.0 \times 0.7-7.0 \mu \mathrm{m}[55]$ \\
\hline & Staphylococcus & 0.34 & 8.75 & $0.5-1.5 \mu \mathrm{m}[56]$ \\
\hline & Romboutsia & 0.26 & 7.33 & $1.2-2 \times 2.3-10 \mu \mathrm{m}$ for Romboutsia sedimentorum [57] \\
\hline & Clostridium & 0.22 & 8.03 & 0.5-1.7× 2.4-7.6 $\mu \mathrm{m}$ for Clostridium butyricum [58] \\
\hline \multirow[t]{7}{*}{ Proteobacteria } & Acinetobacter & 0.90 & 5.92 & $0.9-1.6 \times 1.5-2.5 \mu \mathrm{m}[59]$ \\
\hline & Massilia & 5.7 & 8.79 & $1.0 \times 3.0 \mu \mathrm{m}[60]$ \\
\hline & Sphingomonas & 0.92 & 9.90 & $0.2-1.4 \times 0.5-4.0 \mu \mathrm{m}[61]$ \\
\hline & Methylobacterium & 0.079 & 10.7 & $0.8-1.2 \times 1.0-8.0 \mu \mathrm{m}[62]$ \\
\hline & Rubellimicrobium & 2.1 & 10.9 & 0.6-0.8 × 2.0-4.0 $\mu \mathrm{m}$ for Rubellimicrobium thermophilum [63] \\
\hline & Paracoccus & 0.54 & 8.39 & $0.5-0.9 \mu \mathrm{m}[64]$ \\
\hline & Noviherbaspirillum & 1.7 & 10.2 & $1.0-1.3 \times 1.5-2.0 \mu \mathrm{m}$ for Noviherbaspirillum agri [65] \\
\hline
\end{tabular}

${ }^{a}$ Genera shown in Fig. 2 and detected in air samples for all sampling months have been selected here.

${ }^{b}$ Calculated according to Eq. (1) in the method section. The data of August are excluded for the calculation.

'For each sampling month, a geometric mean of the aerodynamic diameters of a given particle size distribution was computed using the GM calculator version 1.0 [66]. Then, the mean of the computed monthly-based geometric means of the aerodynamic diameters was calculated to obtain an annually averaged aerodynamic diameter that is representative for each genus

other particles. Meanwhile, bacterial dispersal relies exclusively on external vectors, such as aeolian dust [15, $81,82]$. Indeed, we observed that dry deposition of bacteria was correlated well with wind velocities, although the results are not statistically significant, with Spearman's $\rho=0.67-0.68$ (Table S4), indicating that bacteria sedimented from the atmosphere are likely of aeolian origin. Thus, bacterial cells are more likely to be attached to other particles that might have higher material densities, e.g., $>2.0 \mathrm{~g} \mathrm{~cm}^{-3}$ for abiotic particles [83], than the densities of biological materials themselves, e.g., 1.1$1.2 \mathrm{~g} \mathrm{~cm}^{-3}$ for bacteria [84], $0.8-1.4 \mathrm{~g} \mathrm{~cm}^{-3}$ for fungal spores [85], and $0.4-1.2 \mathrm{~g} \mathrm{~cm}^{-3}$ for pollen grains [85]. Thus, bacterium-specific attachment to abiotic particles might explain the cause of their larger sedimentation velocities than those of fungi and plants.

\section{Precipitation dominates bacterial deposition from the atmosphere}

On average, $95 \%$ of bacterial deposition is carried out via precipitation, indicating that precipitation is the dominant mode of atmospheric bacterial deposition. However, an anomalous tendency was observed in May during which only $4.1 \%$ of bacteria were precipitated and the remaining $95.9 \%$ were sedimented (Table S2). The large bacterial sedimentation in May is likely to be due to the small precipitation amount (Fig. 1b), in conjunction with the high atmospheric bacterial concentration (Fig. 3). The high bacterial concentration in May is possibly due to high concentrations of non-bacterial particles, such as Asian dust and airborne pollen, which are known to increase in Korea during the spring months $[43,86-88]$ and serve as external vectors for bacteria dispersal [15, 89-91].

\section{Distinct bacterial microbiotas between precipitation and sedimentation}

We observed significantly different bacterial communities in precipitation from those in sedimentation and the air (Fig. 3c,d), while their memberships in sedimentation were not significantly different from those in the air (Fig. 3c). These findings are in congruence with a previous 


\section{a}

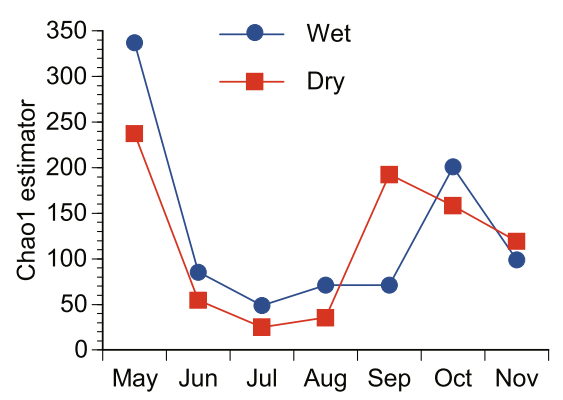

C

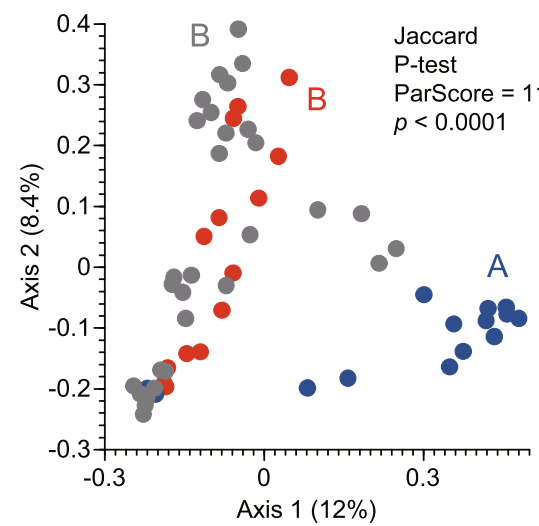

b

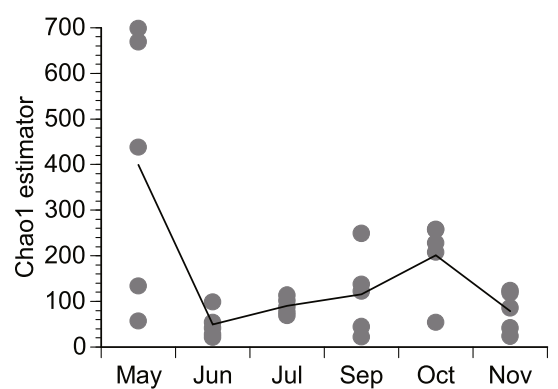

d

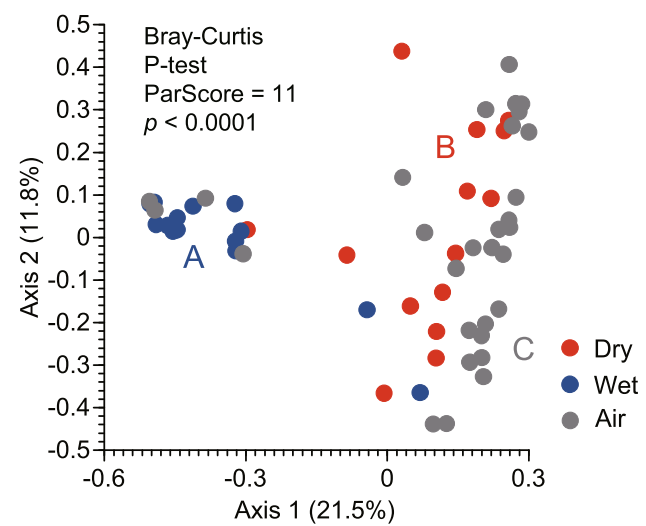

Fig. 5 Bacterial diversity in deposition and air samples. a Chao 1 estimates of the number of $97 \%$ of the operational taxonomic units (OTUs) in the deposition samples. $\mathbf{b}$ Chaol estimates of the number of $97 \%$ of the OTUs in the air samples. Each point represents a datum of each particle size bin for each month. The line indicates the mean particle size-resolved results for each month. $\mathbf{c}$ Principal coordinate analysis plot of bacterial memberships in terms of the Jaccard indices, based on 97\% OTUs. Significant differences for pair-wise comparisons are indicated by different letters (a and $\mathbf{b})$. d Principal coordinate analysis plot of the bacterial structures in terms of the Bray-Curtis distances, based on $97 \%$ OTUs. Significant differences for pair-wise comparisons are indicated by different letters $(\mathbf{a}, \mathbf{b}$, and $\mathbf{c})$

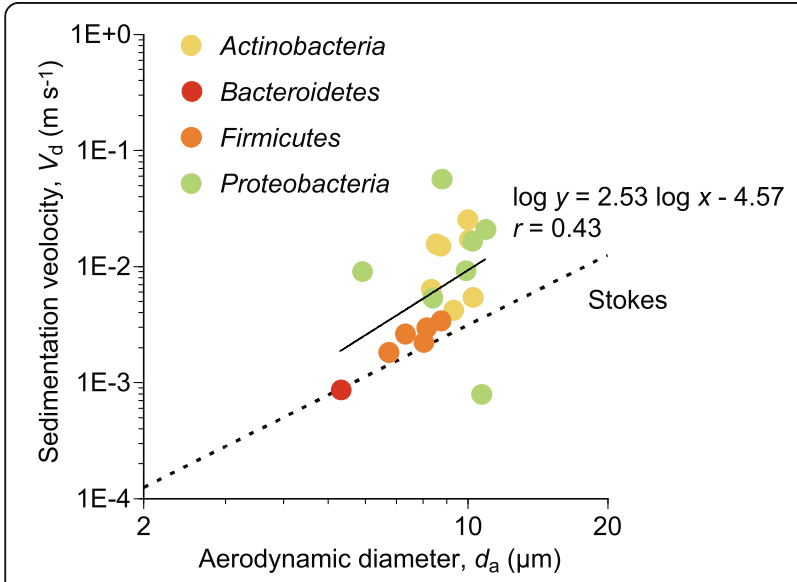

Fig. 6 Relationship between the sedimentation velocities $\left(V_{d}\right)$ and aerodynamic diameters $\left(d_{\mathrm{a}}\right)$ of atmospheric bacteria. Each point represents one datum for each genus. The genera in Table 1 are shown. Theoretical terminal settling velocities $\left(V_{\text {stk }}\right)$, given by Stokes' law (denoted by the dashed line), are included for comparison report that bacterial compositions in the free troposphere were similar to those in sedimentation (dry deposition) but not similar to those in precipitation (wet deposition) at high-elevation sites in Spain [39].

The bacterial genera specifically enriched in precipitation included Aquabacterium, Bradyrhizobium, Burkholderia, Mucilaginibacter, and Novosphingobium, while those abundant in both precipitation and sedimentation included Massilia, Methylobacterium, Noviherbaspirillum, and Sphingomonas (Fig. 2). Noviherbaspirillum and Massilia have been reported to be abundant in rainwater collected at high-elevation sites in Spain [39]. Burkholderia, Massilia, Methylobacterium, and Mucilaginibacter have been reported to be abundant in rainwater collected at mountain sites in China [36], while Aquabacterium, Massilia, Methylobacterium, Novosphingobium, and Sphingomonas are similarly abundant in cloud water collected at another mountain site in China [92]. Genera such as Bradyrhizobium, Methylobacterium, and 
Table 2 Comparison of atmospheric properties of biological particles ${ }^{\text {a }}$

\begin{tabular}{lllll}
\hline Type & Contribution of precipitation to total deposition & Aerodynamic diameter, $\boldsymbol{d}_{\mathbf{a}}(\boldsymbol{\mu m})$ & Sedimentation velocity, $\boldsymbol{V}_{\mathbf{d}}\left(\mathbf{c m} \mathbf{~ s}^{-\mathbf{1}}\right)$ & $\mathbf{R e f e r e n c e}$ \\
\hline Bacteria & $95 \%$ & 8.84 & 1.72 & This study \\
Fungi & $86 \%$ & 5.93 & 0.80 & [17] \\
Plants & $13 \%$ & n.d. & 0.40 & [43] \\
\hline
\end{tabular}

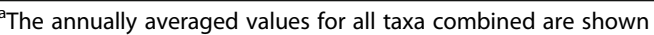

Abbreviation: $n$.d. not determined due to skewed particle size distributions

Sphingomonas are also reported to be abundant in Arctic snow [31].

Nucleation activities are known for some of the bacterial genera abundantly detected in our precipitation samples. For instance, Massilia is known to have an icenucleation active strain [93]. The genus Sphingomonas, which contains several species previously classified in the genus Pseudomonas, is also known to have cloud condensation nuclei and ice-nucleation active strains $[29,94]$. Pseudomonas was not abundant in our precipitation samples collected from spring to fall in Korea, which is in agreement with a previous study that analyzed rainwater collected during summer months in China [36]. Meanwhile, Pseudomonas is reported to be abundant in cloud water collected at a mountain site in France [30]. We do not know the exact causes of these inter-study variabilities. However, we expect that these variabilities might be due in part to spatiotemporal variabilities in the involvement of ice-nucleation active bacteria in processes of cloud formation. For instance, a larger involvement of ice-nucleation active bacteria is expected in colder continental climate zones where the cold rain process dominates, while smaller involvement is expected in warmer maritime climate zones where the warm rain process dominates.

\section{Do bacteria grow in the air?}

We observed taxon-specific bacterial enrichment in precipitation (Fig. 2). As discussed, they might specifically be involved in and play a role in precipitation, for example, by serving as cloud nuclei, since some of the bacteria observed are known to have nucleation potential $[29,93,94]$. In addition, they might also reproduce and increase their populations in cloud droplets [95-100]. Though the in situ evidence is scarce, this hypothesis is supported by laboratory-based experiments that have demonstrated bacterial reproduction in droplets [99, 100]. Furthermore, the literature suggests that only selected microbes can thrive in clouds, and they are likely oligotrophic, psychrotolerant species that can utilize atmospheric components such as organic acids and alcohols as their nutrient sources $[95,98]$, with examples of such bacteria including Burkholderiales, Methylobacterium, and Sphingomonas [95]. We observed enrichment of Burkholderia in our precipitation samples (Fig. 2). Notably, Burkholderia were relatively scarce in the air
(Fig. 4), indicating a possibility that they might selectively reproduce and increase in population in cloud droplets before precipitating from the atmosphere.

\section{Caveats}

As discussed, bacteria might reproduce in cloud water. This means that bacteria might also reproduce in collected rainwater. We do not know exactly to what extent bacterial growth after sample collection has affected our calculations of wet deposition flux densities, even though we recovered collected rainwater samples immediately after each precipitation event and stored them at $-20^{\circ} \mathrm{C}$ to minimize their growth. However, we expect that this artefact is small enough to capture the seasonal tendency of bacterial wet deposition, since a similar seasonal tendency was observed for amounts of precipitation (Fig. 1b), with a strong correlation observed (Fig. S2). It should be also noted that our finding of distinct microbiotas between dry and wet deposition (Fig. 5c,d) was unaffected by possible bacterial growth after sample collection, since the differences were confirmed not only in bacterial structures but also in their memberships, which are thought to be independent of their growth. In addition, bacteria might also reproduce and/or die on substrates of air and dry deposition samplers during a 1month sampling period. However, we expect that the bacterial growth was small enough due to harsh conditions, e.g., desiccation caused by air flow created by the sampler. For instance, a study [101] has reported the monotonical increase of bacterial DNA and stable community structures on an air filter throughout a 21-week sampling period, indicating the stability of bacterial DNA on air filters and substrates at least for a duration of several weeks.

\section{Conclusions}

This study investigated atmospheric bacterial deposition. We found that bacteria had large aerodynamic diameters, likely due to the aggregation and/or attachment to other larger particles, which likely results in their observed large sedimentation velocities from the atmosphere. On average, precipitation contributed to $95 \%$ of total bacterial deposition in our sampling site in Korea. The large contribution of precipitation might be in part due to their large-size particles, which can serve as efficient nuclei in clouds (e.g., as giant cloud condensation 
nuclei). Moreover, we observed distinctly different microbiotas between precipitation and sedimentation, which might indicate specific bacterial involvement and/ or selective bacterial growth in clouds. Overall, our findings provide a novel insight into how bacteria participate in atmospheric processes and the global cycling of substances on Earth, including the water cycle.

\section{Methods}

\section{Precipitation, sedimentation, and air samples}

Previously collected samples on a rooftop (about $20 \mathrm{~m}$ above ground level) of a building in Seoul in Korea $\left(37^{\circ} 27^{\prime} 55.0^{\prime \prime} \mathrm{N} ; 126^{\circ} 57^{\prime} 17.7^{\prime \prime} \mathrm{E}\right)$ from May to November 2015 [17, 43] were analyzed here. Briefly, the sampling site was on a university campus in a hilly suburban forested area in the Seoul Special City, the capital megacity of South Korea. Detailed information of our sampling site, such as the vegetation, topography, climate characteristics, and weather conditions such as temperature, relative humidity, wind velocity, and precipitation, is available in our previous publications [17, 43].

Briefly, deposition samples were collected using an automatic dry and wet deposition sampler [44]. The sampling heights of dry and wet deposition samplers were 1.1 and $0.9 \mathrm{~m}$ from the raised floor which is about $2.3 \mathrm{~m}$ above the rooftop of the building, respectively. Each sedimentation sample was collected on a quartz fiber substrate (47 mm diameter, QR-100; Advantec Tokyo Kaisha, Ltd., Tokyo, Japan) placed on a knifeedge surrogate surface [102] for a duration of 1 month, while each precipitation sample was collected through a polypropylene funnel into a $1 \mathrm{~L}$ polypropylene bottle, from which collected rainwater was recovered into 250 $\mathrm{mL}$ polypropylene bottle(s) immediately after each precipitation event, which typically continued for one to several days. The total collected amounts of precipitation were $620,1520,3110,1400,440,770$, and $1870 \mathrm{~mL}$ for May, June, July, August, September, October, and November, respectively, which correspond to precipitation flux densities of 3.7, 9.1, 18.6, 8.4, 2.6, 4.6, and $11.2 \mathrm{~mL}$ $\mathrm{cm}^{-2}$ month $^{-1}$, respectively (Fig. 1b). Duplicates and travel blanks were also collected. For each sedimentation travel blank, a clean quartz fiber substrate was loaded onto the dry deposition sampler, immediately unloaded, and then placed into a sterile Petri dish and transported to the laboratory. For each precipitation travel blank, 50 $\mathrm{mL}$ of ultrapure water was poured into the polypropylene funnel of the wet deposition sampler, then immediately recovered from the $1 \mathrm{~L}$ polypropylene bottle and decanted into a sterile $50 \mathrm{~mL}$ tube and transported to the laboratory. The collected sedimentation and precipitation samples, including duplicates and travel blanks, were stored at $-20^{\circ} \mathrm{C}$ until subsequent sample processing.
Air samples were collected using an eight-stage Andersen sampler (AN-200; Sibata Scientific Technology Ltd., Tokyo, Japan) with an air flow rate adjusted at 28.3 $\mathrm{L} \mathrm{min}^{-1}$, in which atmospheric particles were sizefractionated and collected on glass fiber substrates $(80$ mm diameter, QR-100; Advantec Tokyo Kaisha, Ltd., Tokyo, Japan) for size bins of $d_{\mathrm{a}}=0.43-0.65,0.65-1.1$, $1.1-2.1,2.1-3.3,3.3-4.7,4.7-7.0,7.0-11$, and $>11 \mu \mathrm{m}$. The sampling height was about $0.4 \mathrm{~m}$ above the rooftop of the building. Air sampling in August failed due to an intense precipitation event. Due to the small bacterial biomass, substrates loaded on the stages of $d_{\mathrm{a}}=0.43$ $0.65,0.65-1.1$, and $1.1-2.1 \mu \mathrm{m}$ were not analyzed. The sampled substrates were kept at $-20^{\circ} \mathrm{C}$.

\section{DNA extraction}

For sedimentation samples, including duplicates and travel blanks, one quarter area of each sampled substrate was used for DNA extraction. For precipitation samples, including duplicates, rainwater samples collected at different rainfall events within a same 1-month sampling period were combined and filtered to recover particulate matters, including bacterial cells, onto a same membrane filter attached to a sterile MiroFunnelTM Filter Funnel ( $47 \mathrm{~mm}$ diameter, $0.45 \mu \mathrm{m}$ pore size, GN-6 Mericel $^{\circ}$ white gridded membrane; Pall Corporation, NY, USA). Similarly, each $50 \mathrm{~mL}$ precipitation travel blank was filtrated through a membrane filter. One quarter area of each filter was used for DNA extraction. For air samples, one eighth area of each sampled substrate was used for DNA extraction. The DNA was extracted using a Power$\mathrm{Max}^{\circ}$ Soil DNA Isolation Kit (Mobio Laboratory, CA, USA) with a modified physical disruption step with supplementary $0.1 \mathrm{~mm}$ diameter glass beads $(300 \mathrm{mg}$ ) and $0.5 \mathrm{~mm}$ diameter glass beads $(100 \mathrm{mg})$ [103] by a bead beater (BioSpec Products, OK, USA). Then, the DNA was purified and eluted into $50 \mu \mathrm{L}$ of TE $(10 \mathrm{mM}$ Tris$\mathrm{HCl}, 1 \mathrm{mM}$ EDTA, $\mathrm{pH}=8.0)$ according to the kit protocol.

\section{Quantitative PCR}

Universal bacterial qPCR assays were performed with forward primer 5' - TCCTACGGGAGGCAGCAGT-3', reverse primer 5'-GGACTACCAGGGTATCTAATCC TGTT-3', and a TaqMan probe (6-FAM)-5'-CGTATT ACCGCG GCTGCTGGCAC-3' -(BHQ1), targeting 331 to 797 region of Escherichia coli's 16S rRNA gene [104]. Each of the $50 \mu \mathrm{L}$ qPCR mixtures contained $25 \mu \mathrm{L}$ of $2 \times$ TaqMan Universal PCR Master Mix (Life Technologies, CA, USA), $1 \mu \mathrm{L}$ of the $10 \mu \mathrm{M}$ probe, $1 \mu \mathrm{L}$ of each of the $10 \mu \mathrm{M}$ primers, $20 \mu \mathrm{L}$ of nuclease-free water, and $2 \mu \mathrm{L}$ of a DNA template. PCR assays were performed on an QuantStudio $^{\text {ta }} 6$ Flex Real-time PCR system (Applied Biosystems, Waltham, MA, USA) with a condition of 12 
min at $95^{\circ} \mathrm{C}$ for initial denaturation, followed by $45 \mathrm{cy}$ cles of $15 \mathrm{~s}$ at $95^{\circ} \mathrm{C}$ for denaturation, $45 \mathrm{~s}$ at $56^{\circ} \mathrm{C}$ for annealing, and $90 \mathrm{~s}$ at $72^{\circ} \mathrm{C}$ for extension. A standard template was prepared by amplifying the DNA extract from the cultured E. coli strain (ATCC 25922) by conventional PCR, using the same primers for qPCR. The amplicon was purified and quantified for its mass concentration by a Quant-iT PicoGreen dsDNA reagent kit (Life Technologies), from which the number concentration of the amplified 16S rRNA gene fragments was calculated based on their length (i.e., $466 \mathrm{bp}$ ). The amplicon was serially diluted to prepare standard templates with concentrations ranging from $10^{1}$ to $10^{6}$ fragment copy number $(\mathrm{CN}) \mu \mathrm{L}^{-1}$. All assays were technically in triplicate. No inhibition was found according to a method reported elsewhere [103]. Here, a 10\% DNA extraction efficiency was assumed to calculate the bacterial quantities on the sampled substrates or filters [103]. The results were reproducible with an $81 \%$ cumulative coefficient of variation based on duplicates for deposition samples (Fig. S2a).

\section{DNA sequencing}

DNA libraries were prepared according to a method reported elsewhere [105]. Briefly, the same primer sets, which were used for qPCR, with adaptor sequences for Illumina MiSeq, were used to amplify bacterial $16 \mathrm{~S}$ rRNA genes. Each reaction mixture $(30 \mu \mathrm{L})$ contained $15 \mu \mathrm{L}$ of the $2 \times$ PCR Solution Premix Taq ${ }^{\text {ma }}$ (Takara Bio Inc., Otsu, Shiga, Japan), $1 \mu \mathrm{L}$ of each of the $10 \mu \mathrm{M}$ primers, and $1 \mu \mathrm{L}$ of a DNA template. PCR was performed with a condition of $5 \mathrm{~min}$ at $95^{\circ} \mathrm{C}$ for initial denaturation, followed by 35 cycles of $15 \mathrm{~s}$ at $95^{\circ} \mathrm{C}$ for denaturation, $45 \mathrm{~s}$ at $56^{\circ} \mathrm{C}$ for annealing, and $90 \mathrm{~s}$ at $72{ }^{\circ} \mathrm{C}$ for extension, and completed by extension for 10 min at $72^{\circ} \mathrm{C}$. No travel blanks were amplified. The amplicons were purified by AMPure XP beads (Beckman Coulter, Inc., CA, USA). The purified amplicons were indexed using the Nextera XT Index kit (Illumina, Inc., CA, USA) with a condition of $3 \mathrm{~min}$ at $95^{\circ} \mathrm{C}$ for initial denaturation, followed by 8 cycles of $30 \mathrm{~s}$ at $95^{\circ} \mathrm{C}$ for denaturation, $30 \mathrm{~s}$ at $55^{\circ} \mathrm{C}$ for annealing, and $30 \mathrm{~s}$ at $72{ }^{\circ} \mathrm{C}$ for extension, and completed by extension for $5 \mathrm{~min}$ at $72{ }^{\circ} \mathrm{C}$. The resultant amplicons were purified by AMPure XP beads and quantified using the Quant-iT PicoGreen dsDNA reagent kit (Life Technologies). The quantified amplicons were normalized, pooled with an internal control PhiX (30\%), and loaded onto a v3 600 cycle-kit reagent cartridge (Illumina) for $2 \times 300 \mathrm{bp}$ paired-end sequencing by Illumina MiSeq.

\section{DNA sequence processing and analyses}

MiSeq Reporter version 2.5 (Illumina) was used to trim the primer and multiplexing barcode sequences and remove reads with quality scores below 20. Next, USEARCH version 11.0.667 [106] was used to join the forward and reverse reads and then remove lowquality reads with $>1.0$ expected errors and/or those with lengths less than $200 \mathrm{bp}$. After quality trimming, the UPARSE-OTU algorithm [107] was used to cluster unique sequences into $97 \%$ operational taxonomic units (OTUs) and remove chimeric reads. Using the SINTAX algorithm [108], each OTU was taxonomically assigned against RDP training set v16 (rdp_16s_v16.fa.gz) [109] with a cutoff confidence value of 0.5 [110]. For diversity analyses, libraries were rarefied to 8000 sequence reads using the "phyloseq" package [111] on $R$ version 3.4.0, which was also used to calculate $\alpha$-diversity measures and distance matrices for $\beta$-diversity analyses. The Jaccard indices for assemblage memberships and Bray-Curtis similarity coefficients for assemblage structures were calculated, for which parsimony tests (P-tests) were performed to compare the bacterial assemblages between air, dry, and wet deposition samples using mothur version 1.39.5 [77]. The reproducibility of characterizing bacterial assemblages was confirmed based on duplicates for deposition samples (Fig. S3b, c), with smaller intra-sample distances than intersample distances in terms of both their memberships and structures (Fig. S3d,e).

\section{Data analyses}

Taxon-specific bacterial concentrations were obtained by the multiplication of sequence relative abundances by the total bacterial concentrations obtained by qPCR $[66,112]$. The geometric mean of the aerodynamic diameter of a given particle size distribution was computed using the GM calculator, version 1.0 [66]. Then, the arithmetic mean of the computed monthly geometric mean aerodynamic diameter was calculated to provide an aerodynamic diameter representative for each bacterial taxon. The bacterial sedimentation velocity $\left(V_{\mathrm{d}}\right) \quad\left(\mathrm{cm} \mathrm{s}^{-1}\right)$ was calculated according to the following equation:

$$
V_{d}=\sum_{j=1}^{6} F_{j} / \sum_{j=1}^{6} \sum_{i=1}^{5} N_{j, i}
$$

where $F_{j}$ is the sedimentation flux density $\left(\mathrm{CN} \mathrm{cm}{ }^{-2}\right.$ month $^{-1}$ ) quantitated for the $j$ th month by the dry deposition sampler, and $N_{j, i}$ is the volumetric concentration $\left(\mathrm{CN} \mathrm{m}^{-3}\right)$ in the $i$ th particle size bin for the $j$ th month measured by the Andersen sampler. The August data were excluded due to the failure of air sampling. For this calculation, the units were converted from $\mathrm{m}$ to $\mathrm{cm}$, and from month to second if necessary. The calculated sedimentation velocities 
were compared with theoretical terminal settling velocities $\left(V_{\text {Stk }}\right)$, given by Stokes' law:

$$
V_{\text {Stk }}=\rho_{0} d_{a}^{2} g / 18 \eta
$$

where $\rho_{0}$ is the standard density $\left(1.0 \mathrm{~g} \mathrm{~cm}^{-3}\right), g$ is the acceleration of gravity $\left(980 \mathrm{~cm} \mathrm{~s}^{-2}\right)$, and $\eta$ is the viscosity of air $\left(1.8 \times 10^{-5} \mathrm{~Pa} \mathrm{~s}\right)$.

\section{Supplementary Information}

The online version contains supplementary material available at https://doi. org/10.1186/s40793-020-00369-4.

Additional file 1: Table S1. Numbers of high-quality sequence reads by Illumina MiSeq. Table S2. Flux densities (CN cm-2month-1) of atmospheric bacterial deposition in dry and wet forms. The percentage values in parentheses indicate relative contributions. Table S3. Correlation coefficients between peak aerodynamic diameters of total bacterial particles and parameters related to weather conditions observed in each sampling month. Table S4. Correlation coefficients between deposition flux densities and airborne concentrations of bacteria and parameters related to weather conditions. The Spearman's rank correlation coefficients are shown with or without asterisk $\left({ }^{*}\right)$ representing statistical significance $(p<$ 0.05). Figure S1. Rarefaction curves based on 97\% OTUs of 165 rRNA gene sequences. a Deposition samples. b Air samples. Figure S2. Relationship between amounts of precipitation and flux densities of wet deposition of total bacteria. Figure S3. Reproducibility based onduplicates of deposition samples.

\section{Abbreviations}

OTUs: Operational taxonomic units; QPCR: Quantitative polymerase chain reaction; CN: Copy number; CFU: Colony forming unit

\section{Acknowledgments}

Not applicable.

\section{Authors' contributions}

CW and NY designed the research; CW performed the experiments; CW performed the sequence analyses; CW and NY performed the data analyses; CW and NY wrote and edited the manuscript. All the authors approved the final manuscript.

\section{Funding}

This research was supported by the Basic Science Research Program through the National Research Foundation of Korea (2013R1A1A1004497).

\section{Availability of data and materials}

Raw sequence data are available under the BioProject number PRJNA603417 of NCBI.

\section{Ethics approval and consent to participate}

Not applicable.

\section{Consent for publication}

Not applicable.

\section{Competing interests}

None to declare.

Received: 26 February 2020 Accepted: 28 November 2020 Published online: 10 December 2020

\section{References}

1. Delgado-Baquerizo M, Oliverio AM, Brewer TE, Benavent-González A, Eldridge DJ, Bardgett RD, et al. A global atlas of the dominant bacteria found in soil. Science. 2018;359(6373):320-5.
2. Sunagawa S, Coelho LP, Chaffron S, Kultima JR, Labadie K, Salazar G, et al. Structure and function of the global ocean microbiome. Science. 2015; 348(6237): 1261359.

3. Bowers RM, McLetchie S, Knight R, Fierer N. Spatial variability in airborne bacterial communities across land-use types and their relationship to the bacterial communities of potential source environments. ISME J. 2011;5(4): 601-12.

4. Gusareva ES, Acerbi E, Lau KJX, Luhung I, Premkrishnan BNV, Kolundžija $\mathrm{S}$, et al. Microbial communities in the tropical air ecosystem follow a precise diel cycle. Proc Natl Acad Sci U S A. 2019;116(46):23299-308.

5. Louca S, Mazel F, Doebeli M, Parfrey LW. A census-based estimate of Earth's bacterial and archaeal diversity. PLoS Biol. 2019;17(2):e3000106.

6. Després VR, Huffman JA, Burrows SM, Hoose C, Safatov AS, Buryak G, et al. Primary biological aerosol particles in the atmosphere: a review. Tellus Ser B-Chem Phys Meteorol. 2012;64:15598.

7. Pöschl U, Martin ST, Sinha B, Chen Q, Gunthe SS, Huffman JA, et al. Rainforest aerosols as biogenic nuclei of clouds and precipitation in the Amazon. Science. 2010;329(5998):1513-6.

8. Bowers RM, Lauber CL, Wiedinmyer C, Hamady M, Hallar AG, Fall R, et al. Characterization of airborne microbial communities at a high-elevation site and their potential to act as atmospheric ice nuclei. Appl Environ Microbiol. 2009;75(15):5121-30.

9. Morris CE, Sands DC, Vinatzer BA, Glaux C, Guilbaud C, Buffière A, et al. The life history of the plant pathogen Pseudomonas syringae is linked to the water cycle. ISME J. 2008;2:321-34.

10. Hinds WC. Bioaerosols. Aerosol technology, properties, behavior, and measurement of airborne particles. 2nd ed. New York: Wiley; 1999. p. 394-401.

11. Jacobson AR, Morris SC. The primary air pollutants-viable particles, their occurrence, sources, and effects. In: Stern AC. Air pollution. 3rd. New York: Academic Press; 1976

12. Smith DJ, Jaffe DA, Birmele MN, Griffin DW, Schuerger AC, Hee J, et al. Free tropospheric transport of microorganisms from Asia to North America. Microb Ecol. 2012:64(4):973-85.

13. Smith DJ, Timonen HJ, Jaffe DA, Griffin DW, Birmele MN, Perry KD, et al. Intercontinental dispersal of bacteria and archaea by transpacific winds. Appl Environ Microbiol. 2013;79(4):1134-9.

14. Aller JY, Kuznetsova MR, Jahns CJ, Kemp PF. The sea surface microlayer as a source of viral and bacterial enrichment in marine aerosols. J Aerosol Sci. 2005:36(5):801-12.

15. Yamaguchi N, Ichijo T, Sakotani A, Baba T, Nasu M. Global dispersion of bacterial cells on Asian dust. Sci Rep. 2012;2:525

16. Reche I, D'Orta G, Mladenov N, Winget DM, Suttle CA. Deposition rates of viruses and bacteria above the atmospheric boundary layer. ISME J. 2018; 12(4):1154-62.

17. Woo C, An C, Xu S, Yi S-M, Yamamoto N. Taxonomic diversity of fungi deposited from the atmosphere. ISME J. 2018;12(8):2051-60.

18. Kim E, Kalman D, Larson T. Dry deposition of large, airborne particles onto a surrogate surface. Atmos Environ. 2000:34(15):2387-97.

19. Mahowald N, Albani S, Kok JF, Engelstaeder S, Scanza R, Ward DS, et al. The size distribution of desert dust aerosols and its impact on the earth system. Aeolian Res. 2014;15:53-71.

20. Johnson DB. The role of giant and ultragiant aerosol particles in warm rain initiation. J Atmos Sci. 1982;39(2):448-60.

21. Möhler O, DeMott PJ, Vali G, Levin Z. Microbiology and atmospheric processes: the role of biological particles in cloud physics. Biogeosciences. 2007:4(6):1059-71.

22. Vali G, Christensen M, Fresh RW, Galyan EL, Maki LR, Schnell RC. Biogenic ice nuclei. Part II: Bacterial sources. J Atmos Sci. 1976:33(8):1565-70.

23. Lindow SE, Arny DC, Upper CD. Bacterial ice nucleation: a factor in frost injury to plants. Plant Physiol. 1982;70(4):1084-9.

24. Maki LR, Galyan EL, Chang-Chien M-M, Caldwell DR. Ice nucleation induced by Pseudomonas syringae. Appl Microbiol. 1974;28(3):456-9.

25. Hew CL, Yang DSC. Protein interaction with ice. Eur J Biochem. 1992;203(12):33-42.

26. Obata H, Saeki $Y$, Tanishita J, Tokuyama $T$, Hori H, Higashi $Y$. Identification of an ice-nucleating bacterium KUIN-1 as Pseudomonas fluorescens and its ice nucleation properties. Agric Biol Chem. 1987;51(7):1761-6.

27. Obata H, Nakai T, Tanishita J, Tokuyama T. Identification of an ice-nucleating bacterium and its ice nucleation properties. J Ferment Bioeng. 1989:67(3): $143-7$. 
28. Obata H, Takinami K, Tanishita J-I, Hasegawa Y, Kawate S, Tokuyama T, et al. Identification of a new ice-nucleating bacterium and its ice nucleation properties. Agric Biol Chem. 1990;54(3):725-30.

29. Bauer H, Giebl H, Hitzenberger R, Kasper-Giebl A, Reischl G, Zibuschka F, et al. Airborne bacteria as cloud condensation nuclei. J Geophys Res Atmos. 2003;108(4658):D21.

30. Amato $P$, Parazols $M$, Sancelme M, Laj P, Mailhot G, Delort A-M. Microorganisms isolated from the water phase of tropospheric clouds at the Puy de Dôme: major groups and growth abilities at low temperatures. FEMS Microbiol Ecol. 2007;59(2):242-54.

31. Mortazavi R, Attiya S, Ariya PA. Arctic microbial and next-generation sequencing approach for bacteria in snow and frost flowers: selected identification, abundance and freezing nucleation. Atmos Chem Phys. 2015; 15(11):6183-204.

32. Mortazavi R, Hayes $C T$, Ariya PA. Ice nucleation activity of bacteria isolated from snow compared with organic and inorganic substrates. Environ Chem. 2008:5(6):373-81.

33. Sands D, Langhans VE, Scharen AL, De Smet G. The association between bacteria and rain and possible resultant meteorological implications. J Hungarian Meteorol Serv. 1982;86:148-52.

34. Morris CE, Conen F, Alex Huffman J, Phillips V, Pöschl U, Sands DC Bioprecipitation: a feedback cycle linking earth history, ecosystem dynamics and land use through biological ice nucleators in the atmosphere. Glob Change Biol. 2014;20(2):341-51

35. Hoose C, Kristjánsson JE, Burrows SM. How important is biological ice nucleation in clouds on a global scale? Environ Res Lett. 2010;5(2):024009.

36. Lu Z, Du P, Du R, Liang Z, Qin S, Li Z, et al. The diversity and role of bacterial ice nuclei in rainwater from mountain sites in China. Aerosol Air Qual Res. 2016;16(3):640-52.

37. Hoose C, Kristiánsson JE, Chen J-P, Hazra A. A classical-theory-based parameterization of heterogeneous ice nucleation by mineral dust, soot, and biological particles in a global climate model. J Atmos Sci. 2010;67(8): 2483-503.

38. Cáliz J, Triadó-Margarit X, Camarero L, Casamayor EO. A long-term survey unveils strong seasonal patterns in the airborne microbiome coupled to general and regional atmospheric circulations. Proc Natl Acad Sci U S A. 2018;115(48):12229-34.

39. Triadó-Margarit X, Caliz J, Reche I, Casamayor EO. High similarity in bacterial bioaerosol compositions between the free troposphere and atmospheric depositions collected at high-elevation mountains. Atmos Environ. 2019;203: 79-86.

40. Els N, Larose C, Baumann-Stanzer K, Tignat-Perrier R, Keuschnig C, Vogel TM et al. Microbial composition in seasonal time series of free tropospheric air and precipitation reveals community separation. Aerobiologia. 2019;35(4): 671-701.

41. Hiraoka S, Miyahara M, Fujii K, Machiyama A, Iwasaki W. Seasonal analysis of microbial communities in precipitation in the greater Tokyo Area, Japan. Front Microbiol. 2017;8:1506.

42. Polymenakou PN, Mandalakis M, Stephanou EG, Tselepides A. Particle size distribution of airborne microorganisms and pathogens during an intense African dust event in the eastern Mediterranean. Environ Health Perspect. 2008;116(3):292-6.

43. Dong K, Woo C, Yamamoto N. Plant assemblages in atmospheric deposition. Atmos Chem Phys. 2019;19(18):11969-83.

44. Han JS, Seo YS, Kim MK, Holsen TM, Yi SM. Total atmospheric mercury deposition in forested areas in South Korea. Atmos Chem Phys. 2016;16(12): 7653-62.

45. Andersen AA. New sampler for the collection, sizing, and enumeration of viable airborne particles. J Bacteriol. 1958;76(5):471-84.

46. Busse H, Wieser M, Buczolits S. Arthrobacter. In: Whitman WB, Rainey F, Kämpfer P, Trujillo M, Chun J, DeVos P, et al., editors. Bergey's manual of systematics of Archaea and Bacteria. Hoboken: Wiley; 2015

47. Kim S-J, Lee S-S. Amnibacterium kyonggiense gen. Nov., sp. nov., a new member of the family Microbacteriaceae. Int J Syst Evol Microbiol. 2011; 61(1):155-9.

48. Stackebrandt E, Schumann P. Blastococcus. In: Whitman WB, Rainey F, Kämpfer $P$, Trujillo M, Chun J, Devos P, et al., editors. Bergey's manual of systematics of Archaea and Bacteria. Hoboken: Wiley; 2015.

49. Jones AL, Goodfellow M. Rhodococcus. In: Whitman WB, Rainey F, Kämpfer P, Trujillo M, Chun J, Devos P, et al., editors. Bergey's manual of systematics of Archaea and Bacteria. Hoboken: Wiley; 2015.
50. Stackebrandt E, Schumann P. Kocuria. In: Whitman WB, Rainey F, Kämpfer P, Trujillo M, Chun J, Devos P, et al., editors. Bergey's Manual of Systematics of Archaea and Bacteria. Hoboken: Wiley; 2015.

51. Buczolits S, Busse HJ. Brachybacterium. In: Whitman WB, Rainey F, Kämpfer $P$, Trujillo M, Chun J, Devos P, et al., editors. Bergey's manual of systematics of Archaea and Bacteria. Hoboken: Wiley; 2015.

52. Patrick S, McDowell A. Propionibacterium. In: Whitman WB, Rainey F, Kämpfer P, Trujillo M, Chun J, Devos P, et al., editors. Bergey's manual of systematics of Archaea and Bacteria. Hoboken: Wiley; 2015.

53. Khan H, Chung EJ, Jeon CO, Chung YR. Mucilaginibactergynuensis sp. nov., isolated from rotten wood. Int J Syst Evol Microbiol. 2013;63(9): 3225-31.

54. Logan NA, DeVos P. Bacillus. In: Whitman WB, Rainey F, Kämpfer P, Trujillo M, Chun J, Devos P, et al. Bergey's manual of systematics of Archaea and Bacteria. Hoboken: Wiley; 2015.

55. Bosshard PP. Turicibacter. In: Whitman WB, Rainey F, Kämpfer P, Trujillo M, Chun J, Devos P, et al., editors. Bergey's manual of systematics of Archaea and Bacteria. Hoboken: Wiley; 2015

56. Schleifer K, Bell JA. Staphylococcus. In: Whitman WB, Rainey F, Kämpfer P, Trujillo M, Chun J, Devos P, et al., editors. Bergey's manual of systematics of Archaea and Bacteria. Hoboken: Wiley; 2015.

57. Wang Y, Song J, Zhai Y, Zhang C, Gerritsen J, Wang H, et al. Romboutsia sedimentorum sp. nov., isolated from an alkaline-saline lake sediment and emended description of the genus Romboutsia. Int J Syst Evol Microbiol. 2015;65(4):1193-8.

58. Rainey FA, Hollen BJ, Small AM. Clostridium. In: Whitman WB, Rainey F, Kämpfer P, Trujillo M, Chun J, Devos P, et al., editors. Bergey's manual of systematics of Archaea and Bacteria. Hoboken: Wiley; 2015.

59. Juni E. Acinetobacter. In: Whitman WB, Rainey F, Kämpfer P, Trujillo M, Chun $J$, Devos P, et al., editors. Bergey's manual of systematics of Archaea and Bacteria. Hoboken: Wiley; 2015

60. The Editorial Board. Massilia. In: Whitman WB, Rainey F, Kämpfer P, Trujillo M, Chun J, Devos P, et al., editors. Bergey's Manual of Systematics of Archaea and Bacteria. Hoboken: Wiley; 2015.

61. Yabuuchi E, Kosako Y. Sphingomonas. In: Whitman WB, Rainey F, Kämpfer $P$, Trujillo M, Chun J, Devos P, et al., editors. Bergey's manual of systematics of Archaea and Bacteria. Hoboken: Wiley; 2015.

62. Green PN. Methylobacterium. In: Whitman WB, Rainey F, Kämpfer P, Trujillo M, Chun J, Devos P, et al., editors. Bergey's manual of systematics of Archaea and Bacteria. Hoboken: Wiley; 2015.

63. Denner EBM, Kolari M, Hoornstra D, Tsitko I, Kämpfer P, Busse H-J, et al. Rubellimicrobium thermophilum gen. Nov., sp. nov., a red-pigmented, moderately thermophilic bacterium isolated from coloured slime deposits in paper machines. Int J Syst Evol Microbiol. 2006;56(6):1355-62.

64. van Spanning RJ, Stouthamer AH, Baker SC, van Verseveld HW. Paracoccus. In: Whitman WB, Rainey F, Kämpfer P, Trujillo M, Chun J, Devos P, et al., editors. Bergey's manual of systematics of Archaea and Bacteria. Hoboken: Wiley; 2015

65. Chaudhary DK, Kim J. Noviherbaspirillum agri sp. nov., isolated from reclaimed grassland soil, and reclassification of Herbaspirillum massiliense (Lagier et al., 2014) as Noviherbaspirillum massiliense comb. nov. Int J Syst Evol Microbiol. 2017;67(5):1508-15.

66. Yamamoto N, Nazaroff WW, Peccia J. Assessing the aerodynamic diameters of taxon-specific fungal bioaerosols by quantitative PCR and nextgeneration DNA sequencing. J Aerosol Sci. 2014;78:1-10.

67. Fang Z, Ouyang Z, Zheng H, Wang X. Concentration and size distribution of culturable airborne microorganisms in outdoor environments in Beijing, China. Aerosol Sci Technol. 2008;42(5):325-34

68. Górny R, Dutkiewicz J, Krysińska-Traczyk E. Size distribution of bacterial and fungal bioaerosols in indoor air. Ann Agric Environ Med. 1999;6(2):105-13.

69. Shaffer BT, Lighthart B. Survey of culturable airborne bacteria at four diverse locations in Oregon: urban, rural, forest, and coastal. Microb Ecol. 1997;34(3): 167-77.

70. Tong $Y$, Lighthart $B$. The annual bacterial particle concentration and size distribution in the ambient atmosphere in a rural area of the Willamette Valley, Oregon. Aerosol Sci Technol. 2000;32(5):393-403.

71. Větrovský $T$, Baldrian $P$. The variability of the 165 rRNA gene in bacterial genomes and its consequences for bacterial community analyses. PLoS One. 2013;8(2):e57923.

72. Després VR, Nowoisky JF, Klose M, Conrad R, Andreae MO, Pöschl U. Characterization of primary biogenic aerosol particles in urban, rural, and 
high-alpine air by DNA sequence and restriction fragment analysis of ribosomal RNA genes. Biogeosciences. 2007;4(6):1127-41.

73. Cao C, Jiang W, Wang B, Fang J, Lang J, Tian G, et al. Inhalable microorganisms in Beijing's $\mathrm{PM}_{25}$ and $\mathrm{PM}_{10}$ pollutants during a severe smog event. Environ Sci Technol. 2014;48(3):1499-507.

74. Renard JB, Dulac F, Durand P, Bourgeois Q, Denjean C, Vignelles D, et al. In situ measurements of desert dust particles above the western Mediterranean Sea with the balloon-borne light optical aerosol counter/ sizer (LOAC) during the ChArMEx campaign of summer 2013. Atmos Chem Phys. 2018:18(5):3677-99.

75. Ryder CL, Marenco F, Brooke JK, Estelles V, Cotton R, Formenti P, et al. Coarse-mode mineral dust size distributions, composition and optical properties from AER-D aircraft measurements over the tropical eastern Atlantic. Atmos Chem Phys. 2018;18(23):17225-57.

76. Zweifel UL, Hagström Å, Holmfeldt K, Thyrhaug R, Geels C, Frohn LM, et al. High bacterial $16 \mathrm{~S}$ rRNA gene diversity above the atmospheric boundary layer. Aerobiologia. 2012;28(4):481-98.

77. Horneck G, Klaus DM, Mancinelli RL. Space microbiology. Microbiol Mol Biol Rev. 2010;74(1):121-56.

78. Smith DJ. Microbes in the upper atmosphere and unique opportunities for astrobiology research. Astrobiology. 2013:13(10):981-90.

79. Salimifard P, Rim D, Gomes C, Kremer P, Freihaut JD. Resuspension of biological particles from indoor surfaces: effects of humidity and air swirl. Sci Total Environ. 2017;583:241-7.

80. Niklas KJ. The aerodynamics of wind pollination. Bot Rev. 1985;51(3):328-86.

81. Griffin D, Garrison V, Herman J, Shinn E. African desert dust in the Caribbean atmosphere: microbiology and public health. Aerobiologia. 2001;17(3):203-13.

82. Griffin DW. Atmospheric movement of microorganisms in clouds of desert dust and implications for human health. Clin Microbiol Rev. 2007;20(3):459-77.

83. Hu M, Peng J, Sun K, Yue D, Guo S, Wiedensohler A, et al. Estimation of sizeresolved ambient particle density based on the measurement of aerosol number, mass, and chemical size distributions in the winter in Beijing. Environ Sci Technol. 2012;46(18):9941-7.

84. Lewis CL, Craig CC, Senecal AG. Mass and density measurements of live and dead gram-negative and gram-positive bacterial populations. Appl Environ Microbiol. 2014:80(12):3622-31.

85. Gregory PH. The microbiology of the atmosphere. London: Leonard Hill Books Ltd.; 1961.

86. Oh J-W, Lee H-B, Kang I-J, Kim S-W, Park K-S, Kook M-H, et al. The revised edition of korean calendar for allergenic pollens. Allergy Asthma Immunol Res. 2012;4(1):5-11.

87. Jung M-I, Son S-W, Kim HC, Kim S-W, Park RJ, Chen D. Contrasting synoptic weather patterns between non-dust high particulate matter events and Asian dust events in Seoul, South Korea. Atmos Environ. 2019;214:116864.

88. Kim S-W, Yoon S-C, Kim J. Columnar Asian dust particle properties observed by sun/sky radiometers from 2000 to 2006 in Korea. Atmos Environ. 2008; 42(3):492-504

89. Ambika Manirajan B, Ratering S, Rusch V, Schwiertz A, Geissler-Plaum R, Cardinale $\mathrm{M}$, et al. Bacterial microbiota associated with flower pollen is influenced by pollination type, and shows a high degree of diversity and species-specificity. Environ Microbiol. 2016;18(12):5161-74.

90. Manirajan BA, Maisinger C, Ratering S, Rusch V, Schwiertz A, Cardinale M, et al. Diversity, specificity, co-occurrence and hub taxa of the bacterialfungal pollen microbiome. FEMS Microbiol Ecol. 2018;94(8):fiy112.

91. Yamaguchi N, Baba T, Ichijo T, Himezawa Y, Enoki K, Saraya M, et al. Abundance and community structure of bacteria on Asian dust particles collected in Beijing, China, during the Asian dust season. Biol Pharm Bull. 2016;39(1):68-77.

92. Wei M, Xu C, Chen J, Zhu C, Li J, Lv G. Characteristics of bacterial community in cloud water at Mt tai: similarity and disparity under polluted and non-polluted cloud episodes. Atmos Chem Phys. 2017;17(8):5253-70.

93. Jimenez-Sanchez C, Hanlon R, Aho KA, Powers C, Morris CE, Schmale DG. Diversity and ice nucleation activity of microorganisms collected with a small unmanned aircraft system (sUAS) in France and the United States. Front Microbiol. 2018;9:1667.

94. Ponder MA, Gilmour SJ, Bergholz PW, Mindock CA, Hollingsworth B, Thomashow MF, et al. Characterization of potential stress responses in ancient Siberian permafrost psychroactive bacteria. FEMS Microbiol Ecol. 2005;53(1):103-15.
95. Amato P, Joly M, Besaury L, Oudart A, Taib N, Moné Al, et al. Active microorganisms thrive among extremely diverse communities in cloud water. PLoS One. 2017;12(8):e0182869.

96. Womack AM, Bohannan BJM, Green JL. Biodiversity and biogeography of the atmosphere. Phil Trans R Soc B. 2010;365(1558):3645-53.

97. Hill KA, Shepson PB, Galbavy ES, Anastasio C, Kourtev PS, Konopka A, et al. Processing of atmospheric nitrogen by clouds above a forest environment. J Geophys Res Atmos. 2007;112(D11):D11301.

98. Amato P, Demeer F, Melaouhi A, Fontanella S, Martin-Biesse AS, Sancelme $M$, et al. A fate for organic acids, formaldehyde and methanol in cloud water: their biotransformation by micro-organisms. Atmos Chem Phys. 2007; 7(15):4159-69

99. Dimmick RL, Wolochow H, Chatigny MA. Evidence for more than one division of bacteria within airborne particles. Appl Environ Microbiol. 1979; 38(4):642-3.

100. Sattler B, Puxbaum H, Psenner R. Bacterial growth in supercooled cloud droplets. Geophys Res Lett. 2001;28(2):239-42.

101. Luhung I, Wu Y, Xu S, Yamamoto N, Chang WW-C, Nazaroff WW. DNA accumulation on ventilation system filters in university buildings in Singapore. PLoS One. 2017;12(10):e0186295.

102. Yi S-M, Holsen TM, Noll KE. Comparison of dry deposition predicted from models and measured with a water surface sampler. Environ Sci Technol. 1997;31(1):272-8.

103. Hospodsky D, Yamamoto N, Peccia J. Accuracy, precision, and method detection limits of quantitative PCR for airborne bacteria and fungi. Appl Environ Microbiol. 2010;76(21):7004-12.

104. Nadkarni MA, Martin FE, Jacques NA, Hunter N. Determination of bacterial load by real-time PCR using a broad-range (universal) probe and primers set. Microbiology. 2002;148:257-66.

105. Xu S, An C, Kim S, Lee S, Lee K, Yamamoto N. Effects of the biocides on the culturable house dust-borne bacterial compositions and diversities. Hum Ecol Risk Assess. 2016;22(5):1133-46.

106. Edgar RC. Search and clustering orders of magnitude faster than BLAST. Bioinformatics. 2010;26(19):2460-1.

107. Edgar RC. UPARSE: highly accurate OTU sequences from microbial amplicon reads. Nat Methods. 2013;10(10):996-8.

108. Edgar RC. SINTAX: a simple non-Bayesian taxonomy classifier for $16 \mathrm{~S}$ and ITS sequences. bioRxiv. 2016(074161).

109. Cole JR, Wang Q, Fish JA, Chai B, McGarrell DM, Sun Y, et al. Ribosomal database project: data and tools for high throughput rRNA analysis. Nucleic Acids Res. 2013;42(D1):D633-42.

110. Edgar RC. Accuracy of taxonomy prediction for $16 \mathrm{~S}$ rRNA and fungal ITS sequences. PeerJ. 2018:6:e4652.

111. McMurdie PJ, Holmes S. phyloseq: An R package for reproducible interactive analysis and graphics of microbiome census data. PLOS ONE. 2013;8(4): e61217.

112. Dannemiller K, Lang-Yona N, Yamamoto N, Rudich Y, Peccia J. Combining real-time PCR and next-generation DNA sequencing to provide quantitative comparisons of fungal aerosol populations. Atmos Environ. 2014;84:113-21.

\section{Publisher's Note}

Springer Nature remains neutral with regard to jurisdictional claims in published maps and institutional affiliations.

Ready to submit your research? Choose BMC and benefit from

- fast, convenient online submission

- thorough peer review by experienced researchers in your field

- rapid publication on acceptance

- support for research data, including large and complex data types

- gold Open Access which fosters wider collaboration and increased citations

- maximum visibility for your research: over $100 \mathrm{M}$ website views per year

At BMC, research is always in progress.

Learn more biomedcentral.com/submissions 